\title{
Formation Of Economically-Effective Model Of Tax Gas Producing Enterprises In The Russian Federation
}

\author{
Anna Balandina \\ Department of World Economy and Taxation \\ National Research Tomsk State University, 36 Lenin \\ Avenue, Tomsk, Russia \\ anbalandina@mail.ru
}

\author{
Kristina Bannova \\ Department of Management \\ National Research Tomsk Polytechnic University, 30 Lenin \\ Avenue, Tomsk,634050, Russia \\ bannovaka@yandex.ru
}

\author{
Yulia Rumina \\ Department of World Economy and Taxation \\ National Research Tomsk State University, \\ 36 Lenin Avenue, Tomsk, Russia
}

\begin{abstract}
Article represents the dynamic approach for diversification effectiveness assessment of company town Berezovsky that modifies the structure of it economy towards the multisectoral one. The effectiveness concept is considered as comparison between stated goals and opportunities to reach them. The authors evolved an autoregressive model with distributed lags of the first order type to describe the dependence between the share of the core industry in dispatched goods on its previous value and on the share of investments in core industry. The core industry of Berezovsky company town is mining operations including fossil fuels extraction and extraction of other minerals. The autoregressive model allows forecasting the share of dispatched goods in mining operations. Making the conclusion on opportunities to achieve the diversification targets let authors evaluate the diversification effectiveness.
\end{abstract}

Keywords-dynamic approach; company town; diversification; factors; effectiveness; autoregression model

\section{INTRODUCTION}

For roughly twenty years, major oil and gas producing states have granted severance tax exemptions, reductions, incentives, and credits to oil and gas producers for the purpose of stimulating exploration, field development, production, and job creation. It must be emphasized that the formation of an effective tax mechanism that allows on the one hand, to solve the problem of providing income budgets of different levels, on the other hand, to promote the development of individual businesses and the economy as a whole, is one of the key tasks of the present stage of development of tax policy of the Russian Federation. Development of an efficient tax system requires balancing functions taxes: fiscal and incentive [1,2]. They need to be balanced to the realization of one function is not performed by the other. After all, we must not forget that taxes regulate all economic, financial and manufacturing processes. As noted above, the efficiency of the tax system can be considered in terms of efficiency inherent functions. Current system of taxation of natural resources is dominated by fiscal function, but the realities of modern times require activation of other functions, as well as their interactions [3]. Therefore, the author believes that a fair distribution of the cash flow for all subjects subsoil will drive stimulating and reproductive functions of taxes, and therefore the implementation of the functions inherent in the tax system in the subsoil. On the basis of the above-mentioned challenges of improving taxation of subsoil users and Measuring gas companies the mineral extraction tax authors propose their own methodology for reforming the tax on extraction of mineral resources in terms of gas production with the construction of investment-oriented and resource-efficient taxation system gas producing sector of the Russian economy.

\section{MODEL}

After spending the economic and mathematical analysis the authors designed and proved the optimal level of tax rates on tax on mining with extraction of gas resources. The application of differential rates effectively in parallel strengthening of state control, as evidenced by the world practice. Thus, it is necessary to combine the rigidity of the institutional environment with the flexibility of taxation. [4] In the investment-oriented and resource-efficient taxation system in subsoil should be reflected not only the vector relationship "state - the business", which serves as the business of the taxpayer. In the socially-oriented economy and investmentoriented and resource taxation implies a reflection of interests and other entities wishing to become recipients of income, therefore, must be an equitable distribution of the cash flow, that is, the coordination of interests of all stakeholders subsoil. In this formula sounds threat mineral resource complex. Of course, additional revenues contribute to the economy, but it is necessary that it does not suffer the source of funds, that is responsible for the reproduction of natural resources. World practice of taxation solves this problem, firstly, flexible taxation, and secondly, the presence of the various funds, whose task is to protect the natural resources $[5,6]$.

In the calculations, and the formation of the initial data were carried out the following procedures:

1.1 In our view, the objective nature of the model of rent relations in the mineral complex, aimed at creating an 
effective model of tax gas producing enterprises should be expressed in a number of related systemic effects [4], by which one can judge the effectiveness, and hence the effectiveness of the system of subsoil (Table 1).

TABLE I - EXPECTED EFFECTS IN THE FORMATION OF AN EFFECTIVE MODEL OF TAX GAS PRODUCING ENTERPRISES

\begin{tabular}{|c|c|}
\hline Type of effect & Expected effects \\
\hline Investment effect & $\begin{array}{c}\text { Development of mining, processing industries and } \\
\text { other technologically interconnected industries; } \\
\text { Activation of innovation and investment activities of } \\
\text { mining companies. }\end{array}$ \\
\hline $\begin{array}{l}\text { Reproductive } \\
\text { effects }\end{array}$ & $\begin{array}{l}\text { Reproduction of the mineral resource base in the } \\
\text { qualitative and quantitative aspects, for mixing gas } \\
\text { producing enterprises focus on production at the "fat" } \\
\text { gas. }\end{array}$ \\
\hline $\begin{array}{c}\text { Environmental } \\
\text { effects }\end{array}$ & $\begin{array}{l}\text { Improvement of the environment in mining areas; } \\
\text { Use of environmentally sound technologies. }\end{array}$ \\
\hline $\begin{array}{l}\text { The economic } \\
\text { effect }\end{array}$ & $\begin{array}{l}\text { GDP growth; Growth of GRP ; Maintaining financial } \\
\text { stability of the mining companies. } \\
\text { Reduction of production costs, and consequently, a } \\
\text { reduction of unit costs in related industries. }\end{array}$ \\
\hline $\begin{array}{c}\text { Fiscal (financial) } \\
\text { effect }\end{array}$ & $\begin{array}{c}\text { Growth of budget revenues; Optimization of financial } \\
\text { flows in the budget system; Reduction of regional } \\
\text { disparities }\end{array}$ \\
\hline Social effect & $\begin{array}{l}\text { Improving the living standards of the population; } \\
\text { Improving living standards fuel producing regions of } \\
\text { the Russian Federation; Improved well-being of every } \\
\text { citizen of the country; Development of human capital. }\end{array}$ \\
\hline
\end{tabular}

Preparation of the effects shown in Table 1, will allow Russia to be close to the main purpose - building a highly developed, resource-saving economy.

In our opinion, the implementation of all the criteria in the current system of taxation gas producing enterprises must develop in two directions:

- binding severance tax to the price of the sale of gas, depending on the direction of sales (domestic market, export);

- the introduction of special factors that differentiate the tax rate.

The main reference for the calculation of the optimal tax rate for the tax on mining for gas producing enterprises should be the level of collection of the tax in the consolidated budget of the Russian Federation, as still the main task of the state to ensure the flow of revenues to the budget, including in the form of taxes. It is also necessary to bear in mind that the basis of the tax on mining is the level of rent exemption that is currently in the gas sector is lower than in the oil.

1.2 In order to solve the problem of determining the tax rate tax on mining the extraction of natural resources gas producing sector of the economy, taking into account changes in the price of natural gas resources for years, as well as price differences in the implementation of the domestic gas market and foreign countries use forecasting method based on extrapolation from the known data (volume of gas production in 2009-2013, sales volume and sales prices in areas domestic and export markets) Tables 2 and 3.

TABLE II - GAS PRODUCTION IN RUSSIA AND NATURAL GAS PRICES 2009-2013.

\begin{tabular}{|c|c|c|c|c|}
\hline Year & $\begin{array}{c}\text { Gas } \\
\text { production of } \\
\text { the Russian } \\
\text { Federation, } \\
\text { bln. cubic } \\
\text { meters }\end{array}$ & $\begin{array}{c}\text { Price per } \\
\mathbf{1 , 0 0 0} \text { cubic } \\
\text { meters, the } \\
\text { Russian } \\
\text { market, } \\
\text { rub. }\end{array}$ & $\begin{array}{c}\text { Price per } \\
\mathbf{1 , 0 0 0} \text { cubic } \\
\text { meters, far } \\
\text { abroad, } \\
\text { rub. }\end{array}$ & $\begin{array}{c}\text { Price per } \\
\mathbf{1 , 0 0 0} \text { cubic } \\
\text { meters, } \\
\text { near } \\
\text { abroad } \\
\text { rub. }\end{array}$ \\
\hline $\mathbf{2 0 0 9}$ & 656,434 & 1125,4 & 5238,5 & 2077,4 \\
\hline $\mathbf{2 0 1 0}$ & 653,874 & 1301,1 & 5181,9 & 2672,9 \\
\hline $\mathbf{2 0 1 1}$ & 664,692 & 1652,8 & 7521,5 & 3693,9 \\
\hline $\mathbf{2 0 1 2}$ & 582,702 & 1885,0 & 7452,1 & 5483,7 \\
\hline $\mathbf{2 0 1 3}$ & 651,216 & 2345,5 & 7420,7 & 6416,5 \\
\hline * Site data Federal State Statistics Service, Gazprom, author's calculations \\
\hline \multicolumn{4}{|r|}{} \\
\hline
\end{tabular}

TABLE III- VOLUMES OF GAS AND THE VOLUME OF GAS PRODUCTION FROM 2009-2013

\begin{tabular}{|c|r|r|r|r|}
\hline Year & $\begin{array}{c}\text { Gas sales of } \\
\text { the Russian } \\
\text { Federation, } \\
\text { bln. cubic } \\
\text { meters }\end{array}$ & $\begin{array}{c}\text { Gas sales } \\
\text { far abroad, } \\
\text { bln. cubic } \\
\text { meters }\end{array}$ & $\begin{array}{c}\text { Gas sales } \\
\text { near } \\
\text { abroad, } \\
\text { bln. cubic } \\
\text { meters }\end{array}$ & $\begin{array}{c}\text { Volume of gas } \\
\text { production, } \\
\text { bln. cubic } \\
\text { meters }\end{array}$ \\
\hline $\mathbf{2 0 0 9}$ & 373,438 & 181,109 & 101,889 & 14,1 \\
\hline $\mathbf{2 0 1 0}$ & 365,912 & 192,133 & 95,828 & 16,7 \\
\hline $\mathbf{2 0 1 1}$ & 347,037 & 193,712 & 123,942 & 17,8 \\
\hline $\mathbf{2 0 1 2}$ & 331,566 & 178,283 & 72,854 & 16,2 \\
\hline $\mathbf{2 0 1 3}$ & 335,595 & 178,873 & 136,748 & 16,9 \\
\hline$*$ Site data Federal State Statistics Service, Gazprom, author's calculations \\
\hline
\end{tabular}

1.3. In order to provide a critical analysis of the proposed method of calculating the tax rate is feasible forecasting data in Tables 2 and 3 for the year 2013. To improve the quality of the model, that is, the analysis indicated above indicators, forecasting will be carried out by means of extrapolation. For this purpose, draw an approximation of existing data power polynomials. Taking into account that will run the approximation of economic data, we use polynomials mostly 3rd (4th in the exceptional case) degree. To determine the coefficients of the approximating polynomial will use the method of least squares. Explain this method.

The data in Tables 2-3 are a set of time series. In order to determine the most equitable tax rate, providing a stimulating and effective development of the gas industry, we derive the equations describing the dynamic change of each series, ie carry out an approximation of the known values.

Suppose $f_{1}, f_{2}, \ldots, f_{m}$ approximate values of a netted function $f\left(x_{i}\right)$ at the points of $x_{0 \times} x_{1 \times m,} x_{n}$, in this case, the 
arguments of the function numbers will be examined years. We want to find a polynomial $p(x)=a_{0}+a_{1} x+\cdots+a_{n} x^{n}, \quad$ that it quantity $\sum_{i=1}^{m}\left(f_{i}-p\left(x_{i}\right)\right)^{2}$ reached a minimum of all polynomials of degree $n$, ie, we want to find the coefficients $a_{0}, a_{1}, \ldots a_{n}$, that the sum of squared errors $f_{i}-p\left(x_{i}\right)$ was minimal.

Drawing on the principle of least squares, we come to the problem of minimizing the function, ie, looking for the minimum

$\mathrm{g}\left(a_{0}, a_{1, \ldots} a_{n}\right)=\sum_{i=1}^{m}\left(f_{i}-\left(a_{0}+a_{1} x+\cdots+a_{n} x^{n}\right)\right)^{2}$.

Condition for the minimum of $g$ is the vanishing of all partial derivatives of the first order. Since the polynomial find it ultimately means to determine the numerical values of the coefficients $a_{0}, a_{1}, \ldots, a_{n}$, that and partial derivatives necessary to take on these factors.

Consequently, this means $\frac{\partial g}{\partial a_{j}}\left(a_{0}, a_{1}, \ldots a_{n}\right)=0$, при $j=0,1 \ldots n$.

Writing down these derivatives explicitly, we obtain the relations $\sum_{i=1}^{m} x_{i}^{j}\left(f_{i}-\left(a_{0}+a_{1} x_{i}+\cdots+a_{n} x_{i}^{n}\right)\right)=0$, by $j=0,1 \ldots n$., which are $n+1$ linear equations for $n+1$ неизвестных $a_{0,} a_{1, m} a_{n}$. Collecting coefficients of $a_{i}$ and rewriting the equation in a vector-matrix form, we obtain the system:

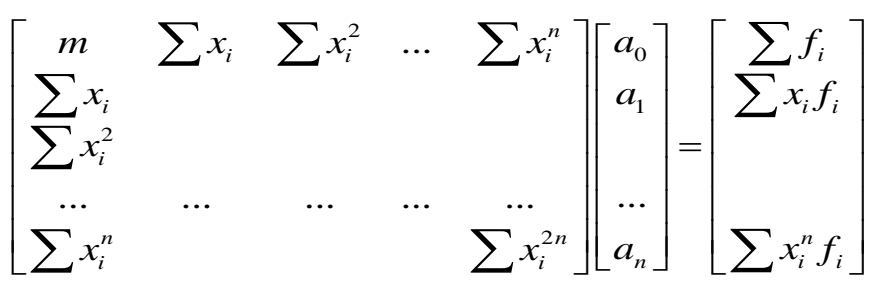

where all the sums are taken from 1 until $m$, where $n$ procedure for approximating polynomial, and $m$ - the number of nodes of the grid function. Based on this system, we obtain the numerical coefficients $a_{0,}, a_{1, \ldots} a_{n}$.

1.4 Using this method, we find that the equation approximating each of the dynamic groups that have the presence of substantial (economically viable) causation, affecting the resulting indicator in the form of revenue from taxes on mining operations in the consolidated budget of the Russian Federation, will be as follows way that shown in Table 4.

TABLE IV APPROXIMATION EQUATIONS FOR DYNAMIC GROUPS

\begin{tabular}{|c|l|}
\hline Dynamic Groups & Approximating functions \\
\hline $\begin{array}{c}\text { The price for the sale of gas to Russia } \\
\text { (F1) }\end{array}$ & $\begin{array}{l}\mathrm{F} 1(\mathrm{x})=4,3583 \times 3- \\
7,075 \times 2+212,37 \mathrm{x}+906,56\end{array}$ \\
\hline The price of gas exports to far abroad & $\mathrm{F} 2(\mathrm{x})=$ \\
& $168,47 \times 2+1674,3 \mathrm{x}+3393,3$ \\
\hline The price of gas exports to CIS & $\mathrm{F} 3(\mathrm{x})=-106,88 \times 3+1065 \times 2-$ \\
\hline
\end{tabular}

\begin{tabular}{|c|l|}
\hline countries (F3) & $1991,9 \mathrm{x}+3139,4$ \\
\hline The volume of gas (F4) & $\mathrm{F} 4(\mathrm{x})=1,8774 \times 3-$ \\
$17,465 \times 2+45,286 \mathrm{x}+625,02$ \\
\hline The volume of sales in Russia (F5) & $\mathrm{F} 5(\mathrm{x})=2,571 \times 3-$ \\
& $21,245 \times 2+38,312 \mathrm{x}+353,78$ \\
\hline The ratio of gas sales to the CIS and & $\mathrm{F} 6(\mathrm{x})=0,0314 \mathrm{x}+0,4807$ \\
\hline Volume of gas production (F7) & $\mathrm{F} 7(\mathrm{x})=-0,0083 \mathrm{x} 3-$ \\
& $0,475 \mathrm{x} 2+3,6333 \mathrm{x}+11,04$ \\
\hline Note & \\
The author's calculations & \\
\hline
\end{tabular}

In order to reduce the effect of multiple factors were calculated root mean square error and the value of the confidence intervals for the trends presented functions F1(x)F7(x). The standard error of the trend defined by the formula:

$$
\sigma_{\bar{f}_{i}}=\sqrt{\frac{\sum_{i=0}^{n}\left(f_{i}-\overline{f_{i}}\right)^{2}}{n}}
$$

where $f_{i}$ - the true values of production volumes, prices and sales volumes, presented in Table 2 and 3.

The values of the confidence intervals $\Delta \mathrm{f}$ determined by multiplying the mean square error $\sigma \overline{f_{n}}$ by trusting the value t $\alpha$ selected from the statistical tables the t-distribution as a function of the level of significance $a=0 ., 05$ and the number of degrees of freedom $(n-m-1)=5-2=3(n=5-$ population size; $m=1-$ number of factor variables): $t \alpha=3,1825$.

1.5 Equation revenues of the consolidated budget from taxes on production in gas producing sector recorded using the functions in Table 3, will be:

Income $=\mathrm{A} \cdot \mathrm{F} 1 \cdot \mathrm{F} 5+\mathrm{B} \cdot \mathrm{F} 2 \quad(\mathrm{~F} 4-\mathrm{F} 5-(\mathrm{F} 4-\mathrm{F} 5) /(1+\mathrm{F} 6)$ F6) $+\mathrm{C} \cdot \mathrm{F} 3((\mathrm{~F} 4-\mathrm{F} 5) /(1+\mathrm{F} 6) \mathrm{F} 6)+\mathrm{D} \cdot \mathrm{F} 7$,

where
A - the rate of sales tax in Russia;
In - the rate of sales tax to foreign countries;
$\mathrm{C}$ - the rate of sales tax in the FSU;
D - rate of tax on sale of associated gas.

Using statistical data processing method, the magnitude of the confidence interval for determining the gain determined by the following formula:

$$
\Delta Д=\sqrt{\sum_{i=1}^{m}\left(\frac{\partial Д}{\partial F_{i}} \Delta f_{i}\right)^{2}}
$$

The optimal tax rate with the introduction of the tax rate dependent on fluctuations in the price of gas for gas-producing organizations are - with the sale of gas to the domestic market of the Russian Federation 12\% of the price of the average sales for the previous calendar year is determined for the next 
fiscal year, adjusted to $15 \%$ (in relation to average annual price increases of $15 \%$ ) for export $5 \%$ of the price of the average sales for the previous calendar year, for the associated gas rate set equal, the tax rate on mining in the implementation of the gas on the Russian domestic market. At this rate of tax revenues of the state, as well as the withdrawal of the rent component in the gas-producing organizations have a tendency to increase with an increase in prices, and also allows you to painlessly for the state to introduce new benefits and incentives to stimulate investment activity resource sector of the economy.

1.6 As a result, the proposed methodological and conceptual positions on the formation of withdrawal of rental income in the form of a tax on mining for gas producing enterprises, depending on the price of gas sales to the domestic and foreign market projected revenues of the consolidated budget will increase by 3 times with 96 billion. In 2013 to 315 bln. in 2014 (projected figures income tax on mining gas producing sector housekeeper Russia in 2014 should amount 124 billion rubles.), with the proposed benefits and preferences 268 billion. rubles. This means that the government will stimulate economic agents to invest in the development of the gas industry about 50 billion rubles., Which also affect the increase in tax collection in the future.

\section{CONCLUSION}

In conclusion, it is worth noting that at the present time in Russia tax on mineral extraction in respect of gas completely indifferent to the quality of reserves and mining conditions. However, the nature of this tax is that no accounting profitability producing fields in taxation leads to the fact that mining companies will certainly fall into the unequal economic conditions. In order to improve the tax laws in the mineral resources and improving the integration of natural resource rents is necessary to introduce a differentiated rate of tax on mineral extraction (MET) in the oil and gas industry. As international experience shows, it will further bring into production as reserves and create a level playing field for all producers, as well as provide for the state to obtain additional tax revenues and improve the social climate in the old oil producing regions due to increased production, extending the life of old fields with remaining reserves. Due to the complexity of determining the number of technical indicators (such as the depth of the gas-bearing strata, the degree of infrastructure development, the degree of magnitude of the field, etc.), as well as complications administered taxes on mining, in the case of administration of multiple differentiation related to gas production seems sufficient to use two basic principles of differentiation MET rates in gas production: by type of gas ("dry" gas and "fat" gas) and in terms of the fields, and thus to the depletion of oil fields. The main effect is achieved by the introduction of such a tax system would allow painless for the consolidated budget to introduce incentives and preferences, and thus to create an investment-oriented and resource taxation system gas producing enterprises.

\section{ACKNOWLEDGEMENT}

The study was financially supported by Russian Humanitarian Science Foundation (RHSF) in the frame of the project for scientific studies (Modeling of conditions of the consolidation of tax liabilities to mitigate the conflict of interest of the state and taxpayers), project No. 15-32-01341.

\section{REFERENCES}

[1] A.C. Fisher, "Resource and Environmental", Cambridge University Press, 1981, pp: 342.

[2] J.H. Hill, "Geological and Economical estimate of mining progects", London, 1993, pp: 231

[3] H. Hoielling, "The Economies of Exhaustible Resources", Journal of Political Economy, vol. 39(2), 1931, pp.137-175.

[4] I.V. Scarf, "Rent-seekers taxation model: the experience of developed countries, and especially Russia", Economy of Russia in XXI century: Sb. scientific. Tr. IV All-Russia. Scientific and Practical Conferenc, 2007, pp: 119-123.

[5] R.Garnaut, "Taxation of Mineral Rents. Oxford", Clarendon Press, 1983, pp:136.

[6] R.Lecomber, "The Economics of Natural Resources", London, MacMillan Press, 1979.

[7] D. J. Leshy, D.C. Wash, "The Mining Law", Resources for the Future. Inc. 1987.

[8] A. Kneese, "The Economics of Natural Resources", Population and Development Review N.Y,, 1988, vol.14, pp. 13-28.

[9] D. Pearce, K. Turner, "Economics of Natural Resources and the Environment", Harvester Wheatsheaf, 1990.

[10]D. Pearce, K. Turner, F. Batsman, "Environmental Economics. An elementary introduction", The John Hopkins University Press. Baltimore, 1993, pp:31.

[11]D.Q. Potts, "Guide to Financing of Mining Progects", Transactions Institute of Mining and Metallurgy.London, 1994

[12] J. Rees, "Natural Resources: Allocation, Economics and Policy", LondonN.Y., 1985.

[13]K.O. Belov, "Improving the mechanism for calculating tax on the extraction of minerals in the gas industry", 2010., pp. 21.

[14] G.U. Boyarko, "Economics of mineral resources", Publishing "AuditInform, 2000, pp. 365.

[15]L.S. Grinkevich, A.S. Balandina, " The introduction of a fair mechanism of tax exemption of differential rent in the gas producing sector", Theory and practice of social development, 2013, vol.3, pp. 187-190.

[16]U.A. Rumina, A.S.Balandina, K.A. Bannova, "Tax incentives of economic entities". Publishing House of the STT, 2014, pp. 295.

[17] Tax Code Part 1, 2.

[18] I. P. Nuzhina, O. B. Yudakhina, E. I. Kotik , E. G. Matyugina "Ecologization of Management Functions as a Factor of Sustainable Development of Construction Industry in Russia", ICEM2015, 2015, pp. 414-417.

[19] N. Chistyakova, V. Spitsin, T. Gromova, N. Shabaldina, A. Dudnikova, "Comparative Investment Analysis of Industries Development in Russia and Germany". Proceedings of the 2015 International Conference on Education Reform and Modern Management, Atlantis Press; 2015; Available from: http://dx.doi.org/10.2991/ermm-15.2015.98 